\title{
Remedial theology: An exploration into the factors- Religious conviction, mysticism and wellbeing.
}

\author{
Dr. Tarundeep \\ GGDSD College, Chandigarh, India.
}

\begin{abstract}
Spirituality and religion have been seen as beneficial, harmful, and irrelevant to health. An effort was made to examine the recent research on this topic. The focus was on: defining spirituality and religion both conceptually and operationally. The rapidly accumulating evidence on spirituality further confirmed that personal spirituality has important influences on healthcare outcomes however it is difficult to integrate into daily medical practice. However medical spirituality was studied as a distinct interdisciplinary with its own well-developed body of clinical evidence, clinical skill and with well-defined clinical boundaries. An effort was made to integrate the new knowledge, and help anticipate developing "turf issues."
\end{abstract}

KEYWORDS: Remedial Theology, Clinical conditioning, Spirituality, Wellbeingness, Mysticism.

\section{INTRODUCTION}

Till the end of the 1990s, spirituality was being discussed at higher education conferences. By the end of the decade the topic was being explored in scholarly literature as well, including professional journals, books, doctoral dissertations, and master's theses. Asking how spirituality was being defined in this emerging discussion was the starting point for this study. Because in qualitative research it is the researcher who serves as the instrument of analysis it is appropriate to reveal the personal interest and perspective of the researcher (Merriam, 2008; Locke, Silverman, \&Spirduso, 2009). Spirituality is not a new word. The idea has long been understood as a dimension of religious experience, especially in the Christian and Buddhist traditions (O'Brien, 1999; McBrien, 1999; Harris, 2011; Wakefield, 2009). It also has been used in a way that separated it from these religious roots; however, it was unclear to me how this new understanding of spirituality was being defined. The present paper worked specifically on these questions, "What do we mean when we say spirituality and why is it important?"

Spirituality - that personal function which relates life's meaning to transpersonal reality. Spirituality is an element of a person's individuality, and is not necessarily defined by association with a certain tradition or by organizational affiliation. It is multidimensional, and operates (to varying degrees) in acknowledgment of the unconscious self, of the needs of others, and of the realm of the sacred. Such awareness varies among individuals and throughout a person's lifetime. Waldfogel has summarized the elements of spirituality as they relate to medical practice. Transpersonal reality here refers to those levels of "world" beyond the ordinary bounds of ego-consciousness. It includes the level of "transcendence" as used by Waldfogel and Cassel.

Religion - the set of beliefs and practices shared by a community in reaching toward the transpersonal reality. This also is a broad term, but describes a more collective element. 
Each religion has its own historical tradition with a rich and complex symbolic language by which to interpret its central symbol of the deepest level of transpersonal reality. Such language may easily be misunderstood by people outside the tradition.

While studying spirituality, religion \& health the term spiritual medicine, emerged which came in as being parallel to such provisions like physical medicine, internal medicine, and behavioral medicine. Further research in the topic lead to understanding spirituality in more general term i.e.medical spirituality, which was better to reflect the broad and complex interconnectivity of many disciplines within this domain. Thus medical spirituality was defined as that area of spirituality studies generally which relates to health effects. It is spirituality seen from a medical point of view. It is the space defined by the overlapping spheres of action, as healthcare and spiritual care seek together to relieve all levels of suffering. Cassel E: (1992) The new literature on spirituality redefined spirituality separate from a religious context. In doing so, it was reinterpreting the very experience of spirituality.

Spirituality defined as Spiritual Development: One of the definitions that equate spirituality and spiritual development. They are represented by the definitions found in the work of Love and Talbot (2009) and Tisdell (2011). Love and Talbot's definition is the first, and most quoted, definition of spirituality. Their definition is based upon three assumptions. The first assumption is that "the quest for spiritual development is an innate aspect of human development; "the second is" spiritual development and spirituality are interchangeable concepts and the third is "openness is a prerequisite to spiritual development". Based upon these assumptions Love and Talbot (2009) offer five propositions that form their definition:

1) Spiritual development involves an internal process of seeking personal authenticity, genuineness, and wholeness as an aspect of identity development.

2) Spiritual development involves the process of continually transcending one's current locus of centricity.

3) Spiritual development involves developing a greater connectedness to self and others through relationships and union with community.

4) Spiritual development involves deriving meaning, purpose, and direction in one's life.

5) Spiritual development involves an increasing openness to exploring a relationship with an intangible and pervasive power or essence that exists beyond human knowing.

Tisdell's (2011) understanding of spirituality is similar to that of Love and Talbot (2009). Her sevenpart definition is based upon several qualitative research studies. Her definition of spirituality is:

1) Spirituality and religion are not the same, but for many people they are interrelated.

2) Spirituality is about an awareness and honoring of wholeness and the interconnectedness of all things through the mystery of what many referred to as the Life-force, God, higher power, higher self, cosmic energy, Buddha nature, or Great Spirit.

3) Spirituality is fundamentally about meaning-making.

4) Spirituality is always present (though often unacknowledged) in the learning environment.

5) Spiritual development constitutes moving toward greater authenticity or to a more authentic self.

6) Spirituality is about how people construct knowledge through largely unconscious and symbolic processes, often made more concrete in art forms such as music, art, image, symbol, and ritual which are manifested culturally.

7) Spiritual experiences most often happen by surprise.

Several general themes are common to both Love and Talbot (2009) and Tisdell (2011). They 
are that spirituality is both deeply individual and communal, that there is some sort of power beyond human existence, and that humans develop in trying to make sense (meaning-making) of their existence in light of this power.

Medical spirituality, as a domain of special clinical interest, education, and research within the healthcare field, encompasses at least the following subject areas:

Clinical basis-Correlations between measures of spirituality and health outcomes Koenig HG, McCullough ME, Larson DB, 2008 provide the foundational knowledge base for the field. Primary clinical skills include recognition and assessment of patient concerns (as a screening function Puchalski C, Romer AL [2009] ; Lo B, Quill T, Tulsky J,2008, for appropriate referral, and recognition of the faith-specific needs of patients and families as they seek to cope with illness. Spirituality concerns are especially likely to be encountered in chronic and progressive disease, critical care, bereavement, stress management, and mental health practice generally.

Philosophical basis - There is growing research in physics, biology and psychology which points to an abstract realm of nonlocal reality, a realm "beyond" the physical for which science generally lacks descriptive language. Clinical evidence for nonlocal effects of intentionality is beginning to emerge in preliminary studies and practitioners attuned to medical spirituality concerns are well-positioned to provide new data about relationships' between physical and psychical ("experiential") realities.

Professional activity - Medical spirituality seeks first of all to foster professional awareness of patients' spiritual needs. Waldfogel writes, "Of course, to engage patients effectively in the spiritual realm, and thereby to offer better and richer support to ill persons and their families, the health care provider must possess a personal and spiritual maturity." Thus an important concern for medical spirituality is providing practitioners appropriate non-sectarian peer support and encouragement of personal spiritual development, and fostering among ourselves the rediscovery of personal meaning in healing practice.

Ethical, legal, social implications - Medical spirituality will be concerned at all levels to be evidencebased and non-sectarian and theologically neutral. It will also need to deal with boundary issues among practitioners of various types since medical spirituality is not without its own special set of concerns and cautions. A special ethical concern is that practitioners restrict themselves to doing what they do well, and make appropriate referrals.

Medical spirituality seeks first of all to foster professional awareness of patients' spiritual needs. Waldfogelwrites, "Of course, to engage patients effectively in the spiritual realm, and thereby to offer better and richer support to ill persons and their families, the health care provider must possess a personal and spiritual maturity."Waldfogel S.1997. Thus an important concern for medical spirituality is providing practitioners appropriate non-sectarian peer support and encouragement of personal spiritual development, and fostering among ourselves the rediscovery of personal meaning in healing practice. The knowledge base and skill base of medical spirituality develop through the interactions of many disciplines, which include, disciplines like, medical specialties, allied health professions, psychology, health education and community services.

Each discipline contributes a special perspective on human experience, which taken together can lead to a deepening general understanding of the many levels involved in healing process. The further development of medical spirituality as a field will benefit from recognizing and respecting the unique contributions of each. 


\section{CONCLUSION}

Examination of the list of interfacing disciplines reveals a variety of boundaries which must be respected if optimum cooperation is to be achieved. There is a more general boundary between "healthcare" and "spiritual care", defining respective areas of expertise, for appropriate consultation and/or referral. An important need of the new field is to identify ethical ways to communicate essential patient care information across this important boundary, especially when one or the other party has information critical to the successful work of the other, in the patient's behalf.

Recognizing medical spirituality as a distinct interdisciplinary field of interest, with its own well-developed body of clinical evidence, clinical skill, and clinical ethics, can help overcome much of the current confusion about how to integrate new knowledge about the influences of spirituality on healthcare outcomes. The new field would also contribute significantly, with other disciplines, to reframing the worldview of healing practice, but more immediately, it could help preempt developing "turf issues" about spiritual care. A formal embrace of the field of medical spirituality would represent a significant evolutionary step, and help us collectively take those understandings to new levels.

\section{REFERENCES}

Bessenger,D.,\& Kuhne,T(2002). Medical Spirtuality: Defining domains \& Boundaries. Southern Medical Journal, 95; 1386-1388.

Cassel E.The nature of suffering and the goals of medicine. N Engl J Med, 1992; 306: 639-645.

Harris, E.H. (2011). Buddhism. In A. Hastings, A. Mason, \& H. Pyper (Eds.) The Oxford companion to Christian thought (pp.82-83). New York: Oxford University Press.

Koenig HG, McCullough ME, Larson DB. Handbook of Religion and Health. New York: Oxford University Press, 2008. (1200 references)

Love, EG. (2006). Spirituality and student development: Theoretical connections. The implications of student spirituality for student affairs practice. New Directions for Student Services,no.95. San Francisco: Jossey-Bass.

Love, EG. (2009). Comparing spiritual development and cognitive development. Journal of College Student Development, 43(3), 357-373.

Love, P.G., \&Estanek, S.M. (2009).Rethinking student affairs practice. San Francisco: Jossey-Bass.

Love, P., \& Talbot, D. (2009).Defining spiritual development: A missing consideration for student affairs. NASPA Journal, 37(1), 361-375.

Love, P.G., \&Yousey, K. (2009). Gaps in the conversation: Missing issues in the discourse of the student affairs field. Journal of College Student Development, 42(5), 430-445.

Lo B, Quill T, Tulsky J. Discussing palliative care with patients. Ann Int Med, 2008; 130: 744-749.

Puchalski C, Romer AL. Taking a spiritual history allows clinicians to understand patients more fully. J Palliative Med, 2009; 3: 129-137.

Lo B, Quill T, Tulsky J. Discussing palliative care with patients. Ann Int Med, 1999; 130: 744-749. 
McBrien, R.P. (Ed.). (1999). The HarperCollins encyclopedia of Catholicism. San Francisco: HarperCollins Publishers Inc.

Merriam, S.B. \& Associates (2008). Qualitative research in practice: Examples for discussion and analysis. San Francisco: Jossey-Bass.

O'Brien, T.C. (1979). Spirituality. In P.K Meagher, T.C. O'Brien, \& C.M. Aherne (Eds.), Encyclopedic dictionary of religion (p. 3371). Washington, DC: Corpus Publications

O'Brien, T.C. (1999). Spirituality. In P.K Meagher, T.C. O'Brien, \& C.M. Aherne (Eds.), Encyclopedic dictionary of religion (p. 3371). Washington, DC: Corpus Publications.

Tisdell,E.J. (2004).The connection of Spirtuality to culturally responsive teaching in Higher Education.Spirtuality in Higher Education News letter,Volume1,Issue (4).

Tisdell, E.J. (2011). Exploring spirituality and culture in adult and higher education. San Francisco: Jossey Bass

Tolliver,D.,Tisdell,E.J.(2002).Bridging across disciplines:Understanding the connections between cultural identity,Spirtuality \& Socio political development in teaching for transformation. Paper presented at the Annual Meeting of the Adult Education Research Conference.

Wakefield, G.S. (2009). Forms of spirituality.In A. Hastings, A. Mason, \& H. Pyper (Eds.). The Oxford companion to Christian thought (pp. 685-686). New York: Oxford University Press.

Waldfogel S. Spirituality in medicine. Primary Care, 1997; 24: 963-976. 